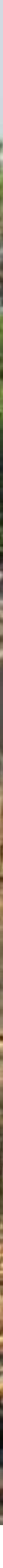

\title{
Counting on forests and accounting for forest contributions in national climate change actions
}

Johnson Nkem

David Oswald

Denboy Kudejira

Markku Kanninen

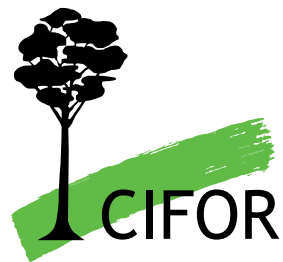





\section{Counting on forests and accounting for forest contributions in national climate change actions}

Johnson Nkem

David Oswald

Denboy Kudejira

Markku Kanninen 


\title{
Working Paper 47
}

(c) 2009, Center for International Forestry Research.

All rights reserved.

Printed in Indonesia

Photo cover by Daniel Tiveau

\author{
CIFOR \\ Jl. CIFOR, Situ Gede \\ Bogor Barat 16115 \\ Indonesia \\ $T+62(251) 8622-622$ \\ $\mathrm{F}+62(251) 8622-100$ \\ E cifor@cgiar.org
}

www.cifor.cgiar.org

This document has been produced with the financial assistance of the European Union (EuropeAid/ENV/2004-81719). The contents of this document are the sole responsibility of the authors and can under no circumstances be regarded as reflecting the position of the European Union.

The participation of various national stakeholders made the study possible. The contributions by staff and students of the Tropical Forests and Climate Change Adaptation project were highly valuable.

\section{Center for International Forestry Research}

CIFOR advances human wellbeing, environmental conservation and equity by conducting research to inform policies and practices that affect forests in developing countries. CIFOR is one of 15 centres within the Consultative Group on International Agricultural Research (CGIAR). CIFOR's headquarters are in Bogor, Indonesia. It also has offices in Asia, Africa and South America. 


\section{Contents}

Acknowledgements ii

Summary iv

1. Introduction 1

2. Study approach 2

3. Climate risks and application of forest ecosystem research 3

4. Some specific recommendations for the second national $\begin{array}{ll}\text { communication report to UNFCCC } & 4\end{array}$

5. Discussion 6

6. Conclusion $\quad 8$

$\begin{array}{lr}\text { References } & 9\end{array}$

$\begin{array}{ll}\text { Annexes } & 12\end{array}$

1. Climate risks listed by each country in their first national communications to UNFCCC

2. TroFFCA and other research relevant to national adaptation activities

3. Specifications for the second national communication report to UNFCCC

4. List of Burkina Faso NAPA priority projects in order of importance

5. Analyses of country reports-first national communication to UNFCCC 


\section{Summary}

This paper constitutes a meta-analysis of the first national communications submitted to the United Nations Framework Convention on Climate Change (UNFCCC) in which important climate risks and opportunities for using forest to alleviate these risks were identified. Gap analyses were carried out in seven case study countries in central America (Costa Rica, Honduras, Nicaragua), west Africa (Burkina Faso, Ghana, Mali) and southeast Asia (Indonesia), which form part of the Tropical Forests and Climate Change Adaptation (TroFCCA) project of the Center for International Forestry Research (CIFOR) and Centro Agronómico Tropical de Investigación y Enseñanza (CATIE).

In addition, the outline for the second national communication to the UNFCCC was reviewed on how forest information could be used to address and overcome some of the gaps identified in the first national communications. As a case study, similar analysis on the use of forest was conducted on the National Adaptation Programme of Action (NAPA) for Burkina Faso.

Although forest is a common theme, there are distinct similarities and differences in the role of forest in the seven countries. In all the countries, forests play an important role in national inventories of greenhouse gases by absorbing carbon dioxide throughout the growth stages. Additionally, forests are globally important as regulating mechanisms in the hydrological cycle. Regional similarities are evident in central American countries in the roles forests play in contributing to hydroelectric activity and in regulating the supply of potable water. There are distinct regional differences between central America, Indonesia and west Africa in both the climate risks and the use of forest. west African countries, for example, are less vulnerable to storms and the resulting deluge-induced inland floods experienced in central America and Indonesia. Land stability as a function of forest management is therefore emphasised in central America and Indonesia. The main message is that forest is important to all seven countries for climate change adaptation. However, each country has unique forms of vulnerability that shape its use of forest goods and services. Thus, the unique context of each country must be considered when formulating climate-change adaptation policies.

The analysis of the NAPA in Burkina Faso highlights the significant and diverse roles that forests play in climate change adaptation. The majority of the NAPA priority projects identified in Burkina Faso are forest based. Thus, forest constitutes an important entry point for NAPA implementation, and success will require measures that enhance forest adaptive capacity. Overall, the full potentials of the use of forest are not strongly emphasised in the national documents on climate change.

An overall conclusion is that climate change adaptation in tropical countries requires substantial information on forests, which must be timely and accurate, and that needs to be integrated into an adaptive management policy framework. 


\section{Introduction}

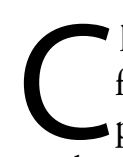
limate change is the biggest risk to stable functioning of the Earth system, and ecosystems play critical roles in mitigation of and adaptation to climate change. Ocean and forest ecosystems absorb roughly half of global anthropogenic carbon dioxide $\left(\mathrm{CO}_{2}\right)$ emissions (Schimel et al. 1996). Changes in temperature affect the rate of ecosystem processes, and elevated levels of carbon dioxide increase the rate of photosynthesis and reduce transpiration (Field et al. 1995; Sellers et al. 1996). Ecosystems are thus an integral part of global climatic processes. There is a dynamic series of feedback relationships that must be considered from an ecosystem perspective when crafting climate-change mitigation or adaptation policies.

Society relies on ecosystems for various goods such as food and timber, regulating services such as water purification, and cultural/aesthetic value (Millennium Ecosystem Assessment 2005). Climate change and greater climate variability - as well as associated disturbances such as floods, droughts and wildfireswill affect the capability of ecosystems to provide necessary goods and services (IPCC 2007). The effects of climate change on ecosystem service provision will differ across regions; for example, there have been high impacts on tropical grasslands and savannahs and low impacts on temperate grasslands (Millennium Ecosystem Assessment 2005). Forest systems globally are responsible for $57 \%$ of water runoff and about 4.6 billion people rely on forests for all or part of their water supply. Biodiversity in tropical forest systems is affected by many different drivers like land use change, pollution and overexploitation, all of which are increasing (in most cases rapidly). Deforestation in the tropics has occurred at an average rate in excess of 12 million hectares per year since the late 1980s. The various changes and drivers of change are affecting the ecosystems services provided by tropical forests (Millennium Ecosystem Assessment 2005).

There is a compelling financial reason for addressing climate change using methods that simultaneously sequester $\mathrm{CO}_{2}$, the principal greenhouse gas in the atmosphere, safeguard other carbon pools from emitting $\mathrm{CO}_{2}$ and also contribute to the adaptation of society to the impacts. ${ }^{1}$ Tropical forests fulfil these roles and are therefore invaluable in global efforts to address climate change. Yet the representation of tropical forests in global climate-change discussions falls short of their full potential contributions. Although mitigation currently dominates the global discussions on climate change, tropical forests remain inseparable from tropical livelihoods and national development - thus, they have a fundamental role in adaptation in tropical regions. Unfortunately, climate change impacts are already affecting the integrity, functioning and provision of forest ecosystem goods and services (Millennium Ecosystem Assessment 2005; IPCC 2007), which in turn affect the majority of rural households who derive their livelihoods from forests. This creates a double challenge of responding to climate change impacts on society and on their sources of livelihood. How these different roles and uses of forest are integrated into national planning and accounted for in global actions requires accurate reporting.

Under the Kyoto Protocol and the United Nations Framework Convention on Climate Change (UNFCCC), countries have a responsibility to show their progress in response to climate change. Unfortunately, the nature and scope of reporting in some developing countries could pose major constraints to assessing global gains made in climate change response, and how best to integrate the roles of tropical forest into national planning strategies. This paper presents an analysis of the first national communications submitted to the UNFCCC Secretariat by selected tropical countries of west Africa, central America and southeast Asia. The countries were selected on the basis of their participation in the Tropical Forests and Climate Change Adaptation (TroFCCA) project undertaken by the Center for International Forestry Research (CIFOR) and Centro Agronómico Tripcal de Investigación y Enseñanza (CATIE). These 'first communications' serve as a review of the use of forests in national climate change reporting. The paper also uses Burkina Faso as a case study to examine the representation of forests in National Adaptation Programmes of Action (NAPAs) as mandated for least developed countries. This study demonstrates ways of using TroFCCA research and other sources of forest-based research findings to supplement the information and materials that need to be incorporated into national communications and other climate change reports of participating countries (e.g., NAPA). TroFCCA research findings are normally shared with international institutions such as the UNFCCC and the Intergovernmental Panel on Climate Change (IPCC). 


\section{Study approach}

The TroFCCA framework (Figure 1) was consistently used as the standard approach in each country for connecting biophysical processes to the ecosystem level, to the landscape level and to the socioeconomic and policy levels. Country-based analyses, however, recognised the contextual differences that required specific adjustments in the application of the methodologies. For example, in Indonesia and Nicaragua, regional models and geospatial analysis were used at the national level to determine areas of vulnerability and risk to climate impacts. In Burkina Faso, Ghana and Mali, regional studies with direct community involvement were more widely used.

The study commenced with a review of the first national communications submitted to the UNFCCC Secretariat as mandated for every Party to the Kyoto Protocol. The risks of climate change as recognised by the different countries involved in the study were summarised. The roles of forests in the response to climate change (as stated in this summary document) were highlighted in order to analyse the strengths and weaknesses in forest use in relation to the identified climate risks. An outline was made of the use of research information from the TroFCCA project in response to the climate risks identified. Following the situation analysis of each country, some recommendations were made for the integration of forest-ecosystem research information into the adaptation strategies (a) in the second national communications to the UNFCCC, (b) in national development policies, and (c) shared with other international institutions. There was also a probe into the NAPA process formulated by least developed countries, using the case of Burkina Faso to examine how forest ecosystem goods and services that contribute to sustaining community livelihoods are reflected in and integrated into the NAPA. Being landlocked in the centre of West Africa, where average annual rainfall rarely exceeding $1000 \mathrm{~mm}$, and with more than $86 \%$ of its total population relying on forest ecosystems for their livelihoods, Burkina Faso presents an example for evaluating the contribution of forest ecosystem goods and services in national climate-change adaptation policies.

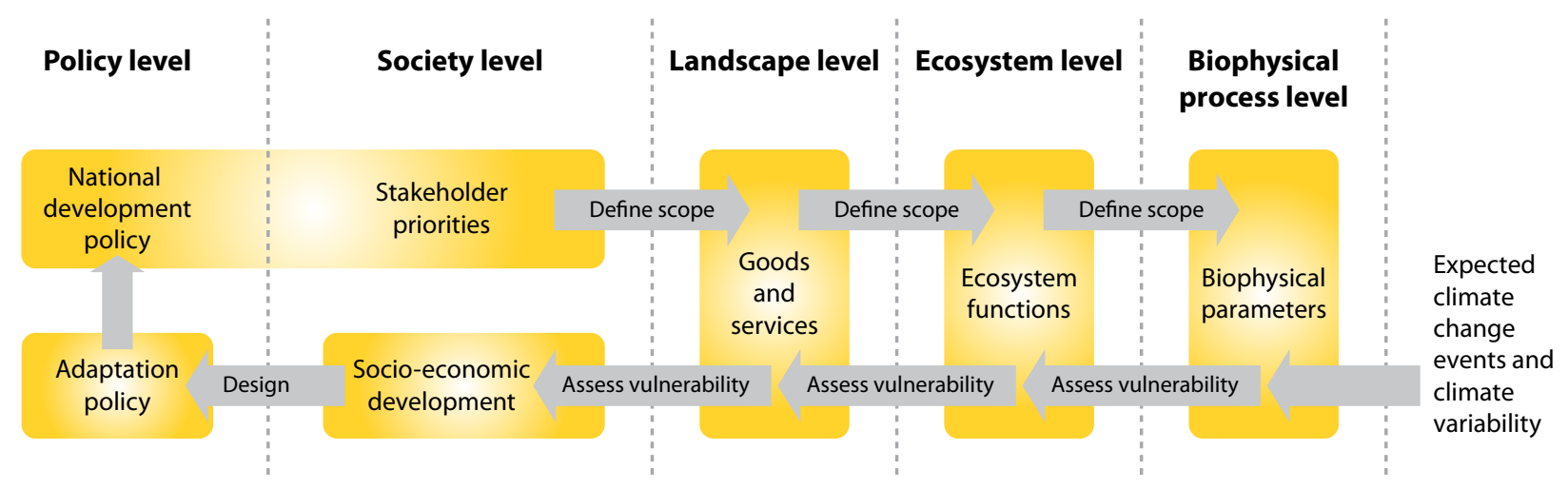

Figure 1. TroFCCA framework guiding the methodology in using ecosystem-based approach for adaptation in coupled human and environment system. 


\section{Climate risks and application of forest ecosystem research}

\subsection{Risks of climate change}

Climate change risks as determined by each of the countries studied (summarised in Annexes 1 and 5) differed among the seven countries. The key areas in which the study nations are exposed to risks are through increased frequency of forest fires, negative impacts on human health due to respiratory problems, greater uncertainty in carbon stock estimates, negative impacts on agricultural productivity and related agro-industries, more droughts, impacts from higher frequency of highenergy storms, and reduced hydroelectric outputs. Most of the countries directly draw attention to a wide range of climate risks on the forest ecosystem. For example, Honduras and Indonesia are particularly concerned with the risk of more fires, Nicaragua on the potential shifts in ecosystems under environmental change drivers, while Burkina Faso and Costa Rica worry about the state and resilience of the forest ecosystem. The risk to agricultural productivity is strongly emphasised by all the west African countries. Climate risk to water resources is commonly listed by most of the countries irrespective of their geographical location and annual precipitation; for example, Burkina Faso and Mali in the Sahel with average annual precipitation of less than $1000 \mathrm{~mm}$ share similar water-risk concerns to Costa Rica, Ghana and Nicaragua that have greater amounts of rainfall.

\subsection{Applicability of TroFCCA research in response to national climate risks}

The ecosystem research outputs from the TroFCCA project have direct implications for climate-change adaptation policy. The results show regionally specific characteristics and national priorities based on social, scientific and economic factors (Nkem et al. 2007). Indonesia is particularly vulnerable to land instability and fires. Africa's primary source of vulnerability is the periodic shortage of potable water, which is exacerbated by deforestation and land use change. central America is vulnerable to high-energy storms and their amplified impacts due to unstable land, as well as shortages of water for human consumption and provision of hydroelectric energy. The principle uses of ecosystem information for climate-change adaptation policy for each TroFCCA country are shown in Annex 2.

Following the guidelines provided by UNFCCC for climate change reporting by Non-Annex 1 Parties in their second national communication (UNFCCC 2004), it is important to emphasise some aspects that are linked to forests and how they could be addressed using forest information. Annex 3 lists examples of some aspects that are linked to forest under the different categories of reporting. 


\section{Specific recommendations for the second national communication report to the UNFCCC}

\subsection{Using forest in addressing adaptation needs in second national communications}

Forest information can be used to explain the linkages between activities and policies related to climate change and other United Nations initiatives such as the Convention on Biological Diversity and the Millennium Development Goals. TroFCCA ecosystem research can be used to explain synergies in adaptation and mitigation objectives, and to provide information on how forests fit into development priorities.

Knowledge of ecosystem health and function is essential to clearly define how mitigation through programmes such as REDD+ (Reducing Emissions from Deforestation and forest Degradation plus co-benefits) may work and support adaptation. Adaptation is also dependent on understanding how forest ecosystems work and may respond to climatic or socioeconomic changes. In Indonesia, the major areas of impact of climate change are forest fires and landslides, which have severe implications on carbon stocks in standing forest and other carbon pools protected by forests. TroFCCA research on forest fire frequency and impacts, vulnerability to landslides, impacts on water resources, etc., can provide information for adaptation measures that benefit mitigation of climate change using forest ecosystems (Santoso 2006, 2007a, b).

Climate change mitigation and adaptation, biodiversity conservation, and poverty alleviation are all fundamentally connected and rely in part on valid and well-formulated ecosystem research. The vulnerability of forest therefore affects both mitigation and adaptation and, consequently, biodiversity conservation and poverty alleviation actions. Accurate data for vulnerability assessment is crucial for climate change policy. This makes it useful and efficient in linking policies that relate to climate change adaptation as well as measures for poverty alleviation and biodiversity conservation (Santoso 2007b).

Capacity to address climate change generally comprises technology and industrial development, education of the population, health, and wellconstructed relationships with various stakeholders. Good relationships among the stakeholders are essential for communication and sharing of expertise and perspectives on climate change mitigation and adaptation. The information from the TroFCCA project about how institutions and stakeholders have been brought together with government agencies serves as a good example of how such relationships could be created and used to formulate a common agenda. This demonstrates the need for information for the development of resilience in institutional relationships using a science-policy dialogue platform.

The work of TroFCCA on tropical forest ecosystem changes in response to climate change, and variability, can also be of use in conjunction with UN Conventions such as that on climate change, biodiversity, sustainable development, MDG etc. Poverty relief is linked to social, economic and environmental vulnerability in Nicaragua. By focusing on community vulnerability and adaptation to climate change, TroFCCA activities are relevant to the Millennium Development Goals on poverty alleviation and environmental sustainability, while also contributing to national capacity building and climate policies (Both Ends 2007).

By estimating changes in carbon sinks and related uncertainties, and providing methodological approaches for evaluating the vulnerability of forest which may contribute to leaks in greenhouse gas emissions, TroFCCA and other forest research information can add value to the national climate-change response. For example, TroFCCA work on ecosystem monitoring, fire detection and prediction, climate risk, and vulnerability can be used to inform national climate-change response actions (Forner et al. 2006) — this is the cornerstone of research activities in Indonesia (Santoso 2006, 2007a).

Forest information-especially on fire and land movement in Indonesia - can be used to explain geographic areas of vulnerability to the adverse effects of climate change, thereby facilitating the implementation of adequate adaptation measures. Guidelines have been developed for the selection of climate scenarios and methodologies for vulnerability assessment in forest ecosystems (Locatelli et al. 2008; Santoso et al. 2008). Similarly, TroFCCA research on changes in forest ecosystem and hydrological function in response to climate change and provision of ecosystem services (Vignola 2005; Hernandez 2006) are crucial in providing adequate adaptation response measures. 
REDD+ mitigation strategies can be described and supported by TroFCCA forest research. Knowledge of ecosystem function and response to climate change and disturbances is essential to REDD+ strategies in mitigating climate change. TroFCCA assessment of ecosystem vulnerability and risk to fire can inform response measures for mitigation. Ecosystem and hydrological functions are essential to carbon-fixation audit processes (Vignola 2005; Hernandez 2006).

TroFCCA's unique approach to bridging scientific research with policy frameworks for ecosystem goods and services in West Africa and Indonesia allows development priorities to be informed by ecosystem information. Integration of climate change into development planning can be augmented with forest-resource vulnerability assessment by TroFCCA (including socioeconomic adaptation strategy). Partnerships with local institutions can be explored to support the need for technology transfer, systemic observation, research, training and capacity building in relation to climate-change mitigation, adaptation and vulnerability analysis.

To overcome some of the constraints and gaps in capacity, technologies such as geographic information systems and remote sensing are required for conducting systematic observation of ecosystems and vulnerability metrics (e.g., fire activity). The work done by TroFCCA in analysing spatial patterns of vulnerability is an example of technological capacity being leveraged to inform development and adaptation policy (Murdiyarso and Adiningshi 2006). Ecosystem service evaluation and ecosystem function research can be used for REDD+ pilot projects and other payment for ecosystem services schemes (Gonzales et al. 2007; Leguía Hidalgo et al. 2007), especially given that there is inadequate national capacity.

\subsection{The role of forests in NAPAs}

The review of the NAPA for Burkina Faso provided data on: community dependency on forest ecosystem goods and services; livelihood sectors most vulnerable to climate change; and priority sectors for climate change adaptation (Annex 4). The use of forest ecosystem goods and services for food, medicines and many other vital commodities is of extreme importance in Burkina Faso. Forest ecosystems provide alternative sources of income, timber, non-timber forest products, recreational and spiritual values, and indirect benefits such as rainfall and temperature regulation. Climate change will have negative effects on the provisioning and functioning of forest ecosystem goods and services. The NAPA of Burkina Faso cites four sectors-water, agriculture, livestock and forestry/biodiversity — as the most vulnerable to climate variability and change. These four sectors are interlinked and directly or indirectly depend on goods and services provided by forest ecosystems. The role of forest ecosystem goods and services is well understood and has been clearly recognised in the NAPA. However, there are still knowledge gaps in the understanding of direct and indirect benefits that communities obtain from forest ecosystems. This lack of a common understanding distorts policy and programme design, and at times hinders the development of cross-sectoral institutional alliances. Most stakeholders outside the forestry sector have little knowledge of the benefits that forest stakeholders derive from forest ecosystem goods and services (Lange 2003). Subsequently, the lack of knowledge can influence programming and implementation of climate-change adaptation interventions that directly impact the sources of wellbeing for rural communities. 


\section{Discussion}

The provision of multiple goods and services by an ecosystem such as forest provides diversity in the range of opportunities that could be used by different countries in addressing their peculiarities and priorities in climate change adaptation, mitigation and vulnerability. Understanding priorities in ecosystem goods and services desired by different communities is crucial in the efficient use of a common response strategy to climate change. Regionally focused ecosystem research can potentially inform development policy, with a view to reducing vulnerability to climate change and climate variability through adaptation strategies.

Forest information is important in formulating climatechange mitigation and adaptation policy for tropical countries, and is only going to be generated through rigorous research. The TroFCCA project addresses the needs of seven tropical countries in developing further capacity in forest research that can be used to develop national climate-change policies as well as to inform reporting to the UNFCCC. The multitiered, systematic framework implemented in this project-which starts with biophysical processes, then links to ecosystem goods and services, and then to policy frameworks that govern human use of forestsis effective in connecting base processes with policies.

West Africa is faced with pressing poverty challenges in addition to the current and future problems posed by climate change. Ecosystems of Burkina Faso, Ghana and Mali are essential to the livelihoods of pastoral people, and climate-change mitigation and adaptation policies must consider this in the process of formulating development policy. The impacts of land use decisions, whether for mitigation or industrial development, can have cascading effects. Additionally, the impacts of climate change may have unforeseen consequences and thus adaptive policies are necessary.

Indonesia is the largest archipelago nation in the world and its geographic positioning exposes it to unique climate change risks compared to the other two regions studied. Extended coastlines are vulnerable to sea level rise as well as to impacts from tsunamis and highenergy storms. Monsoons and precipitation variability have negative impacts on terrain stability, posing risk to development. Conversely, periods of dryness contribute to a higher frequency of forest fires, resulting in destruction of property and risk to human health.
The findings of this report demonstrate that there are distinct regional characteristics that must inform climate-change adaptation policy in each TroFCCA country. In central America, vulnerability to highenergy storms is an acute risk resulting from climate change that, as shown with Hurricane Mitch in 1998, can have significant impacts on society. The role of forests in regulating water provision to society and the hydroelectric sector is a key issue in central America, and research focused on forests should address this.

Some countries in the TroFCCA project have special needs that are distinctive within their region and in some cases globally. Special effort on further developing and generalising vulnerability and adaptation analysis in Indonesia could result in similar applicable system frameworks for other countries in southeast Asia. Nicaragua has a very large amount of $\mathrm{CO}_{2}$ fixed each year $(72,429 \mathrm{Gg})$ due to large tracts of sparsely populated land in the east of the country. Special attention should be given to capitalising on this carbon sink by exploring REDD+ and related carbon-marketbased projects applicable to Nicaragua. Costa Rica has both a special risk and opportunity related to climate change adaptation. The in-country expertise and experience in establishing conservation areas is an excellent basis for testing payment for environmental services programmes. A key risk in Costa Rica is the vulnerable coastline near Puntarenas. Although sea level rise will affect other countries in Central America and globally, the risk is heightened in the tropics because of the relatively high population density in coastal areas and large amount of resources at risk, but with limited capacity to respond. Burkina Faso faces similar challenges to other African countries in relation to climate change and adaptation. However, it has specific requirements for adaptive policy with respect to land use change. Burkina Faso's biogeographical divisions of Sahelian, Sub-Sahelian, North Soudanian and South Soudanian are linked to the corresponding climate and land-use impacts. Conflicts between pastoralists and industrial interests provide the challenge of making relevant policy for a dynamic situation and the opportunity to demonstrate effective frameworks that may be applicable in other regions faced with similar land-use problems. TroFCCA work on forest information and climate change adaptation in Burkina Faso can be used as initial steps in systematic adaptive management in the tropics. 
Systematic research and capacity to deal with climate change through adaptive policies are common to all three regions. Continuous monitoring using remote sensing technology and geographic information systems, modelling and ground-based research is fundamental for determining the functioning of ecosystems and the impacts of climate change. Innovative mitigation programmes such as REDD+ are important strategies for national climate-change adaptation and mitigation. REDD+ programmes have shown some signs of success in their early stages of implementation in regions such as Amazonia and Panama. The payment for environmental services initiatives in Amazonia for small-scale famers, implemented as part of the Proambiente programme, have shown positive signs in creating methods of remuneration for carbon sequestration while concurrently promoting sustainable development and biodiversity conservation (Hall 2008). Challenges to the Proambiente programme, such as a lack of legal frameworks and underfunding, have limited their success (Hall 2008). In Panama, a study with an indigenous community showed potential for carbon sequestration with improved crop-fallow systems and secondary forest development; however, aspects of equitable distribution of wealth still remain (Tschakert 2007). The need for further development of methodologies and tools such as geographic information systems and remote sensing, as well as increased educational and technical capacity were key outcomes of recent UNFCCC meetings about REDD+ programmes (IISD 2008). The work done through the TroFCCA project provides a basis for further regional development of REDD+ programmes with linkages to national climate-change adaptation policies and programmes.

Through the NAPA process, least developed countries have outlined urgent and immediate priorities for climate change adaptation. Burkina Faso prioritised 12 projects predominantly from the livelihood sector, such as agriculture, livestock management, forest ecosystem protection, and development of alternative sources of energy. The multifaceted nature of an ecosystembased adaptation approach provides for cross-sectoral adaptation measures, which, in the NAPA process, strengthens local actions to increase environmental and community resilience to the changing climate.

NAPAs provide an important framework for integrating responses to climate change impacts in the least developed countries. As demonstrated by the case of Burkina Faso, however, the process used for the elaboration of NAPAs is restricted in its capability to adequately address the challenges of climate change. Stakeholder participation is still limited to selective consultations, rather than actual decision making and designing of adaptation measures. Such deficiencies compromise the implementation of NAPA priority projects, particularly because stakeholder collaboration is required across all sectors. The provision of a regular review of NAPA priorities, together with improved collaboration among stakeholders, provides the opportunities for least developed countries to effectively address the challenges of adaptation to climate change. 


\section{Conclusion}

This meta-analysis highlights the important role that forests can play in formulating national climate-change adaptation policies. The outputs of the TroFCCA project demonstrate, for example, the importance of forests in the supply of water resources. Ecosystems are an integral part of the hydrological cycle at regional and global scales. Climate-change adaptation policies in all regions must consider the role of ecosystems in water provision for industrial applications and human consumption. The role of forests in national carbon budgets and mitigation plans is another factor that is common across the case study countries. Climate-change adaptation policies need to be linked with mitigation efforts that recognise the role that forests play as a potential sink or source of carbon. In all regions, the functions of forests should be continuously monitored with a view to understanding impacts of future change in climate and increased climate variability.

Regional similarities were observed throughout this analysis. Countries in southeast Asia are confronted with the geographical reality that they are exposed to ocean-related climate risks, such as higher sea surface levels and extreme storms with high energy and precipitation. Landslides and instability resulting from heavy rainfall pose risks to social and economic wellbeing. Average reduction in precipitation resulting from climate change is predicted to cause a greater number of droughts and forest fires in this region. This will have profound effects on industrial activity in southeast Asian countries. Forest research can inform adaptation policies throughout southeast Asia to help address these common threats. central America is also vulnerable to high-energy storms. Hurricane Mitch was a clear example of how climate-related incidents can have amplified negative impacts due to terrain instability. Forests in central America are important to adaptation by providing land stability as well as by regulating water provision to the hydroelectric industry and to communities. central American adaptation policies are already being supported by TroFCCA outputs. west Africa has challenges with extreme poverty. The key regional commonality in west Africa is the need to understand the dynamics of land use in relation to livelihoods and how this links with climate change impacts. The TroFCCA methodology of linking ecosystem processes, provision of ecosystem goods and services, and development policies, proved to be useful in this respect. 
AMCE (African Ministerial Conference on the Environment) 2008 Climate change adaptation in Africa-scoping paper for the expert group meeting. (Paper to African Ministerial Conference on the Environment-12th meeting of the Expert Group, Johannesburg, South Africa, 7-9 June 2008.) United Nations, New York. 30p.

Both Ends 2007 Adapting to climate change-how local experiences shape the debate. Both Ends Briefing Paper. Both Ends-Environment and Development Service, Amsterdam. 27p.

Burkina Faso 2001 Communication nationale du Burkina Faso. UNFCCC. 132p. http://unfccc. int/essential_background/library/items/3599. php? rec $=$ j\&priref=3461\#beg.

Cervi, F.A.P., Imbach, P., Vallejo, A., Tito, R. and Perez, C.J. 2007 Zonas edafoclimáticas aptas para especies forestales bajo escenarios de cambio climático: un estudio de caso en Costa Rica. TroFCCA central America Briefing Paper. CIFOR, Bogor, Indonesia. 26p.http://www.cifor.cgiar. org/trofcca/_ref/america/docs.htm.

CIFOR 2007 Forest policies and forest resource flow in Burkina Faso, Ghana, and Mali-conflicting or consistent for adaptation to climate change. TroFCCA (Tropical Forests and Climate Change Adaptation) Brief. CIFOR, Bogor, Indonesia. 8p. http://www.cifor.cgiar.org/ trofcca/_ref/america/docs.htm.

Coto, O. 2006 Sector eléctrico e hidroeléctricidad en América Central. Consultancy report: TroFCCA (Tropical Forests and Climate Change Adaptation) Project. http:// www.cifor.cgiar.org/trofcca/_ref/america/docs.htm.

Field, C., Jackson. R. and Mooney, H. 1995 Stomatal responses to increased $\mathrm{CO}_{2}$ : implications from the plant to the global scale. Plant, Cell and Environment 18: 1214-1225.

Forner, C., Nkem, J., Santoso, H. and Perez, C. 2006 Setting priorities for forests in adaptation to climate changeTroFCCA's first year report. CIFOR, Bogor, Indonesia. 56p. http://www.cifor.cgiar.org/trofcca/attachment/ first_annual_report.pdf.

Gonzales, C., Locatelli, B., Imbach, I., Vignola, R., Pérez, C. and Vaast, P. 2007 Identificación de bosques y sistemas agroforestales proveedores de servicios ecosistémicos para el sector agua potable en Nicaragua. Recursos Naturales y Ambiente 51: 35-41.

Gyampoh, B.A., Idinoba, M. and Amisah, S. 2008 Water scarcity under a changing climate in Ghana: options for livelihoods adaptation. Development 51: 415-417.

Hall, A. 2008 Better RED than dead: paying the people for environmental services in Amazonia. Philosophical Transactions of the Royal Society B 363: 1925-1932.

Hernandez, C.G. 2006 Identificación de bosques y sistemas agroforestales importantes proveedores de servicios ecosistémicos para el sector agua potable en
Nicaragua. Tesis Magister Scientiae en Agroforesteria Tropical, Programa de Educación para el Desarrollo y la Conservación. Escuela de Posgrado, Centro Agronomico Tropical de Investigacion y Ensenanza, Costa Rica. http:// www.cifor.cgiar.org/trofcca/_ref/america/docs.htm.

IISD (International Institute for Sustainable Development) 2008 Summary of the UNFCCC workshop on methodological issues relating to reducing emissions from deforestation and ecosystem degradation in developing countries, 25-27 June 2008. Earth Negotiations Bulletin 12(376). 11p. http://www.iisd.ca/climate/wedfd/.

IPCC 2007 Summary for policymakers. In: Parry, M.L., Canziani, O.F., Palutikof, J.P., van der Linden, P.J. and Hanson, C.E. (eds.) Climate change 2007: impacts, adaptation and vulnerability. Contribution of Working Group II to the Fourth assessment report of the Intergovernmental Panel on Climate Change, 7-22. Cambridge University Press, Cambridge, UK.

IRI (International Research Institute) for Climate and Society 2008 IRI at COP-13. http://portal.iri.columbia. edu/portal/server.pt/gateway/PTARGS_0...e/new_ home/homebody/2007_spotlight_features/cop13_ update_1.html.

Kalame, F.B., Idinoba, M., Brockhaus, M. and Nkem, J. 2008 Forest policies and forest resource flow in Burkina Faso, Ghana and Mali: conflicting or consistent for adaptation to climate change? CIFOR, Bogor, Indonesia. http://www.cifor.cgiar.org/trofcca/_ref/africa/docs.htm.

Lange, G.M. 2003 Policy applications of environmental accounting. Environmental Economics Series Paper No. 88. Environment Department, The World Bank, Washington, DC.

Leguía Hidalgo, E.J., Locatelli, B., Imbach, P., Alpízar, F., Vignola, R. and Perez, C. 2007 Identificación de bosques proveedores de servicios ecosistémicos para hidroelectricidad en Nicaragua. Recursos Naturales y Ambiente 51: 41-51. http://www.cifor.cgiar.org/trofcca/_ ref/america/docs.htm.

Leguía, E.J., Locatelli, B., Imbach, P., Pérez, C.J. and Vignola, R. 2008 Servicios ecosistémicos e hidroenergía en Costa Rica. Ecosistemas 17(1): 16-23. http://www. cifor.cgiar.org/trofcca/_ref/america/docs.htm.

Locatelli, B. 2006 Vulnerabilidad de los bosques y sus servicios ambientales al cambio climático. Documento de respaldo para la primera reunión del Proyecto TroFCCA (Bosques Tropicales y Adaptación al Cambio Climático). CIRAD-CATIE. 4p. http://www.cifor.cgiar.org/trofcca/_ ref/america/docs.htm.

Locatelli, B., Herawati, H., Brockhaus, M., Idinoba, M. and Kanninen, M. 2008 Methods and tools for assessing the vulnerability of forests and people to climate change: an introduction. Working Paper No. 43. CIFOR, Bogor, Indonesia. 
Millennium Ecosystem Assessment 2005 Ecosystem and human well being: synthesis. Island Press and World Resources Institute, Washington, DC.

Murdiyarso, D. and Adiningshi, E. 2006 Assessing and mapping of forest ecosystem risk to fires. TroFCCA Methodology Presentation. CIFOR, Bogor, Indonesia. 23p. http://www.cifor.cgiar.org/trofcca/_ref/asia/ docs.htm.

Najarro, T. 2007 Identification of forests providing ecosystem services for socio-economic sectors vulnerable to climate change: drinking water and hydroenergy in Honduras. M.Sc. Thesis, National Autonomous University, Tegucigalpa, Honduras.

Nkem, J., Santoso, H., Murdiyarso, D., Brockhaus, M. and Kanninen, M. 2007 Using tropical forest ecosystem goods and services for planning climate change adaptation with implications for food security and poverty reduction. Journal of Semi-Arid Tropical Agricultural Research 4(1): 1-23.

Pérez, C. 2006 ¿Cómo incluir los bosques y ecosistemas forestales en la adaptación al cambio climático? Documento de respaldo para la primera reunión del Proyecto. TroFCCA (Bosques Tropicales y Adaptación al Cambio Climático). CATIE (Centro Agronomico Tropical de Investigacion y Ensenanza). 4p. http://www. cifor.cgiar.org/trofcca/_ref/america/docs.htm.

Pérez, C., Vignola, R. and Pérez, H.E. 2007a Community based adaptation to climate variability and change in agriculture and water resources in the dry tropics of Nicaragua: the case of San Pedro del Norte. TroFCCA Research Paper. CIFOR, Bogor, Indonesia. 23p. http:// www.cifor.cgiar.org/trofcca/_ref/america/docs.htm.

Pérez, C., Locatelli, B., Vignola, R. and Imbach, P. 2007b Importancia de los bosques tropicales en las políticas de adaptación al cambio climático. Naturales y Ambiente 51: 6-13. http://www.cifor.cgiar.org/trofcca/_ref/america/ docs.htm.

Republic of Ghana Ministry of Environment, Science, and Technology 2000 The first national communication on climate change convention. 172p. http://unfccc.int/ national_reports/non-annex_i_natcom/items/2979.php.

República de Costa Rica Ministerio de Ambiente y Energía 2001 The first national communication on climate change convention. 177p. http://unfccc.int/national_ reports/non-annex_i_natcom/items/2979.php.

República de Honduras Secretaria de Recursos Naturales y Ambiente 2000 The first national communication on climate change convention. 106p. http://unfccc.int/ national_reports/non-annex_i_natcom/items/2979.php.

República de Nicaragua 2001 The first national communication on climate change convention. 127p. http://unfccc.int/national_reports/non-annex_i_natcom/ items/2979.php.

République du Mali Ministère de l'Equipement de l'Amanegement du Territoire de l'Environnement et de l'Urbanisme \& Ministère de l'Education 2000 The first national communication on climate change convention. 106p. http://unfccc.int/national_reports/non-annex_i_ natcom/items/2979.php.
Santoso, H. 2006 Adaptation to recurrent fires and their risks under the influence of climate change and climate variability. Methodology presentation to Global Fire Assessment Workshop, 26-28 April 2006. CIFOR, Bogor, Indonesia. 19p. http://www.cifor.cgiar.org/ trofcca/_ref/asia/docs.htm

Santoso, H. 2007a A rapid vulnerability assessment method for designing national strategies and plans of adaptation to climate change and climate variability. TroFCCA research paper to the 2007 Amsterdam Conference on the Human Dimensions of Global Environmental Change, Amsterdam, Netherlands, 24-26 May 2007. CIFOR, Bogor, Indonesia. 12p. http://www.cifor.cgiar.org/ trofcca/_ref/asia/docs.htm.

Santoso, H. 2007b Linking different perspectives on adaptation for mainstreaming into the development agenda. Methodology presentation TroFCCA ProjectBangladesh. CIFOR, Bogor, Indonesia. 16p. http://www. cifor.cgiar.org/trofcca/_ref/asia/docs.htm.

Santoso, H., Idinoba, M. and Imbach, I. 2008 Climate scenarios: what we need to know and how to generate them. Working Paper No. 45. CIFOR, Bogor, Indonesia.

Schimel, D., Alves, D., Enting, I., Heimann, M., Joos, F., Raynaud, D., Wigley, T., Prather, M., Derwent, R., Enhalt, D. et al. 1996 Radiative forcing of climate change. In: Houghton, J.T., Filho, L.G.M., Callander, B.A., Harris, N., Kattenberg, A. and Maskell, K. (eds.) Climate change 1995: the science of climate change, 65-131. Cambridge University Press, Cambridge, UK.

Sellers. P.J., Bounoua, L., Collatz, G.J., Randall, D.A., Dazlich, D.A., Los, S.O., Berry, J.A., Fung, I., Tucker, C.J., Field, C.B. et al. 1996 Comparison of radiative and physiological effects of doubled atmospheric $\mathrm{CO}_{2}$ on climate. Science 271: 1402-1406.

SP/CONEDD (Secrétariat Permanent du Conseil National pour l'Environnement et le Développement Durable) 2007 Programme d'action national d'adaptation la variabilite et aux changement climatiques (PANA du Burkina Faso). Ministère de l'Environnement et Cadre de Vie, Burkina Faso.

State Ministry of Environment, Indonesia 1999 The first national communication on climate change convention. 116p. http://unfccc.int/national_reports/non-annex_i_ natcom/items/2979.php.

Tschakert, P. 2007 Environmental services and poverty reduction: options for smallholders in the Sahel. Agricultural Systems 94(1): 75-86.

UNFCCC (United Nations Framework Convention on Climate Change) 2004 Reporting on climate change: user manual for the guidelines of national communications from non-Annex I Parties. 31p. http://unfccc.int/ national_reports/nonannex_i_natcom/guidelines_and_ user_manual/items/2607.php.

Vignola, R. 2005 A literature review on forest and hydrological services: perspectives for climate change adaptation. CATIE Grupo Cambio Global, Tropical Adaptation to Climate Change. 45p. http://www.cifor. cgiar.org/trofcca/_ref/america/docs.htm.Nos ea ad dolobor sit inim ipit augait nit ipsusti onsequa mconsecte magna augue dolestio 


\section{Annex 1. Climate risks listed by each country in their first national communications to UNFCCC}

\begin{tabular}{|c|c|c|}
\hline Country & Climate change risks & Information source \\
\hline Indonesia & $\begin{array}{l}\text { - high uncertainty in carbon source and sink data from forest } \\
\text { inventory } \\
\text { - higher incidence of fires as a result of warmer temperatures } \\
\text { and careless land-use practices }\end{array}$ & $\begin{array}{l}\text { State Ministry of Environment, Indonesia } \\
\text { (1999) }\end{array}$ \\
\hline Burkina Faso & $\begin{array}{l}\text { - } \text { risk of drought } \\
\text { - } \text { reduced productivity of cotton industry } \\
\text { - } \text { higher rates of respiratory illness } \\
\text { - } \text { potentially reduced levels of biodiversity }\end{array}$ & Burkina Faso (2001) \\
\hline Ghana & $\begin{array}{l}\text { - } \text { ground and surface water levels reduced } \\
\text { irrigation demand increased } \\
\text { - } \text { agricultural productivity diminished } \\
\text { - } \text { coastal zopulation health negatively affected } \\
\text { risk from sea level rise }\end{array}$ & $\begin{array}{l}\text { Republic of Ghana Ministry of } \\
\text { Environment, Science, and Technology } \\
\text { (2000) }\end{array}$ \\
\hline Mali & $\begin{array}{l}\text { - production of sorghum/millet, maize and cotton agricultural } \\
\text { products may be negatively affected } \\
\text { - availability of potable water resources } \\
\text { - vitality and abundance of fish may be negatively affected } \\
\text { - health of population may be negatively affected }\end{array}$ & $\begin{array}{l}\text { République du Mali Ministère de } \\
\text { l'Equipement de l'Amanegement du } \\
\text { Territoire de l'Environnement et de } \\
\text { I'Urbanisme \& Ministère de l'Education } \\
\text { (2000) }\end{array}$ \\
\hline Costa Rica & $\begin{array}{l}\text { - stress to supply of potable water } \\
\text { - hydroelectric output may be reduced by land degradation, } \\
\text { leading to siltation as well as reduced water supply } \\
\text { - ecosystem states at risk due to climate variability and change }\end{array}$ & $\begin{array}{l}\text { República de Costa Rica Ministerio de } \\
\text { Ambiente y Energía (2001) }\end{array}$ \\
\hline Honduras & $\begin{array}{l}\text { - exposure of populations in dry areas to extreme hunger } \\
\text { and disease } \\
\text { - higher frequency of forest fires } \\
\text { - high-impact precipitation events } \\
\text { - } \text { reduced agricultural output } \\
\text { - sea level rise in coastal communities } \\
\text { uncertainty in carbon stock estimates }\end{array}$ & $\begin{array}{l}\text { República de Honduras Secretaria de } \\
\text { Recursos Naturales y Ambiente (2000) }\end{array}$ \\
\hline Nicaragua & $\begin{array}{l}\text { - risk of drought in the north } \\
\text { - uncertainty in carbon source and sink estimates } \\
\text { growing population susceptible to water shortages } \\
\text { and malaria } \\
\text { - ecosystems that may experience state shifts due to } \\
\text { environmental change drivers }\end{array}$ & República de Nicaragua (2001) \\
\hline
\end{tabular}




\section{Annex 2. TroFFCA and other research relevant to national adaptation activities}

\begin{tabular}{|c|c|c|}
\hline Region & Country & Ecosystems adaptation response \\
\hline $\begin{array}{l}\text { Southeast } \\
\text { Asia }\end{array}$ & Indonesia & $\begin{array}{l}\text { - Climate-environment knowledge from tools created to forecast vulnerability in climate-sensitive } \\
\text { regions improving decision-support systems (IRI for Climate and Society 2008) } \\
\text { - TroFCCA focus on fire management and sustainable forest management will help inform } \\
\text { adaptation strategy and goals expressed in } 1 \text { st National Communication } \\
\text { - Land movement data will assist in charting areas of vulnerability, potentially linking ecosystem } \\
\text { pattern with climate change drivers }\end{array}$ \\
\hline \multirow[t]{3}{*}{ West Africa } & $\begin{array}{l}\text { Burkina } \\
\text { Faso }\end{array}$ & $\begin{array}{l}\text { Burkina Faso's different biogeographical regions (Sahelian, Sub-Sahelian, North Soudanian and } \\
\text { South Soudanian) must be understood from a scientific standpoint to see how climate change will } \\
\text { affect ecosystems and societies in these regions. TroFCCA research supports these efforts } \\
\text { - Conversion of land for industrial cotton production in central south Burkina Faso has resulted in } \\
\text { deforestation and displacement of farmers and pastoralists (CIFOR 2007). Adaptive management } \\
\text { policies are necessary in these cases to respond to the cascading effects of land-use decisions. } \\
\text { Forest information and land-use studies from TroFCCA inform these policies }\end{array}$ \\
\hline & Ghana & $\begin{array}{l}\text { Water scarcity and its relation to resource use and adaptation is a key aspect of development } \\
\text { policy for Ghana, and TroFCCA work on forests will help to inform decision making related to } \\
\text { development policy (Gyampoh et al. 2008) } \\
\text { - TroFCCA work supports distributive and adaptive policy making linked to ecosystem research, } \\
\text { which is an underlying requirement in west Africa. In Ghana, the connections between ecosystem } \\
\text { function, climate-change impacts and land-use conflicts are examined through field research } \\
\text { programmes. The results of these studies can inform adaptation and mitigation initiatives for } \\
\text { climate change (CIFOR 2007) }\end{array}$ \\
\hline & Mali & $\begin{array}{l}\text { The synergies between degradation of forests and desertification augmented by climate change, } \\
\text { as well as ecosystem resilience, must be understood. TroFCCA ecosystem research can support this } \\
\text { (AMCE 2008) } \\
\text { - TroFCCA work on the social use of ecosystems can inform forest policies that are adaptive to } \\
\text { shocks of climate change (Forner et al. 2006) } \\
\text { - Ecosystem function in Mali in relation to changing parameters such as water availability must } \\
\text { be clearly understood in order to respond to climate change. The TroFCCA research forms a } \\
\text { foundation for capacity for systematic monitoring of the environment and social factors }\end{array}$ \\
\hline \multirow[t]{3}{*}{$\begin{array}{l}\text { Central } \\
\text { America }\end{array}$} & Costa Rica & $\begin{array}{l}\text { Forests are integral in mitigating and adapting to climate-imposed risks to hydrological cycles. } \\
\text { Research and understanding of how forests interact within water basins is critical to understanding } \\
\text { how the effects of climate change on water systems will be observed. Additionally, impacts on } \\
\text { hydroelectric supply can be understood by TroFCCA research on ecosystems (Leguia et al. 2008) } \\
\text { - TroFCCA research on ecosystems, agroforestry and vulnerability to drought can help to create } \\
\text { adaptive capacity with respect to climate variability and extreme weather events (Pérez et al. } \\
2007 b) \text { Ecosystem change and adaptation to climate change is important to understanding } \\
\text { how forests may change, as well as how different environmental parameters may contribute to } \\
\text { ecosystem changes in various contexts. TroFCCA research on forest species change will inform this } \\
\text { area (Cervi et al. 2007) }\end{array}$ \\
\hline & Honduras & $\begin{array}{l}\text { TroFCCA work on assessing the role of ecosystems in providing potable water in the drought- } \\
\text { vulnerable western region will help deal with climate change risk (Najarro 2007) } \\
\text { - TroFCCA work on analysing the contribution of ecosystems in the supply of hydroelectric } \\
\text { power will help manage social and economic risks to climate change and variability (Coto 2006; } \\
\text { Najarro 2007) } \\
\text { - TroFCCA research on including ecosystems in adaptation policy will help conceptually link on-the- } \\
\text { ground research with national sustainable-development policy (Pérez 2006) }\end{array}$ \\
\hline & Nicaragua & $\begin{array}{l}\text { Forests are integral in mitigating and adapting to climate-imposed risks to the hydroelectric } \\
\text { industry. Research and understanding of how forests interact with the hydrological cycle, } \\
\text { particularly in relation to watersheds, will inform adaptation policy (Leguía et al. 2007) } \\
\text { - TroFCCA research on ecosystems, agroforestry and vulnerability to drought can help to } \\
\text { create adaptive capacity with respect to climate variability and extreme weather events } \\
\text { (Pérez et al. 2007a) } \\
\text { - The supply of potable water is noted as an acute source of risk to regions such as San Pedro del } \\
\text { Norte (Gonzales et al. 2007; Pérez et al. 2007a). TroFCCA-provided knowledge of forest function } \\
\text { with respect to provision of ecosystem services such as water regulation and supply will assist with } \\
\text { adaptive-management policy development (Locatelli 2006) }\end{array}$ \\
\hline
\end{tabular}




\section{Annex 3. Specifications for the second national communication report to the UNFCCC}

\section{National circumstances}

The guidelines state that the

information on national circumstances provides the opportunity for detailing the national or, as relevant, regional development priorities, objectives and circumstances that serve as the basis for addressing issues relating to climate change. Information provided on national circumstances is critical for understanding a country's vulnerability, its capacity and its options for adapting to the adverse effects of climate change, as well as its options for addressing its GHG [greenhouse gas] emissions within the broader context of sustainable development.

\section{National greenhouse gas inventories}

The guidelines state that

a national greenhouse gas inventory is a key element of the national communication. As an introduction, this section should include information on how inventory work is organized and carried out.

\section{General description of steps taken or envisaged to implement the convention}

Paragraph 25 of the guidelines states that:

Each non-Annex I Party shall, in accordance with Article 12, paragraph 1 (b), communicate to the conference of the Parties a general description of steps taken or envisaged by the Party to implement the Convention, taking into account its common but differentiated responsibilities and specific national and regional development priorities, objectives and circumstances.

\section{Measures to facilitate adequate adaptation to climate change}

Following the guidelines for the second national communication,

The information in this section should include a description of activities, measures and programmes that are being undertaken or planned in the country to adapt to climate change. These activities, measures, and programmes should be regularly updated as financial, technical and data resources become available.

\section{Measures to mitigate climate change}

Articles 4.1 and 12.1 of the Convention commit Parties to

develop national and, where appropriate, regional programmes and measures that will result in the mitigation of human-induced climate change. Such measures may either reduce the increase in greenhouse gas emissions (abatement) or increase terrestrial storage of carbon (sequestration).

\section{Other information}

This section of the guidelines request for

the provision of other information considered relevant to the achievement of the objectives of the Convention. This information could include relevant national, social, economic, and environmental policies and activities geared towards the implementation of the Convention.

\section{Constraints and gaps, and related financial technical and capacity needs}

The second national communication requires,

Taking into account Article 4, paragraph 7, and Article 4, paragraphs 3 and 5, of the Convention, the extent to which developing country Parties will effectively implement their commitment to communicate information will depend on the implementation by developed country Parties of their commitment under the Convention relating to financial resources and the transfer of technology. Accordingly it is important to include information on the constraints and gaps and the related financial, technical and capacity needs. 


\section{Annex 4. List of Burkina Faso NAPA priority projects in order of importance}

\begin{tabular}{|c|c|}
\hline $\begin{array}{l}\text { Project } \\
\text { number }\end{array}$ & Project title \\
\hline 1 & $\begin{array}{l}\text { Reducing vulnerability to climate changes through the strengthening of a prevention and food-crisis } \\
\text { management system }\end{array}$ \\
\hline 2 & $\begin{array}{l}\text { Securing cereal production through the promotion of supplemental irrigation in: North Region (Oudalan Province) } \\
\text { and Centre-North region (Namentenga Province) }\end{array}$ \\
\hline 3 & Restoration and management of Oursi pond \\
\hline 4 & Fodder production and development of fodder for livestock in the Sahelian region of Burkina Faso \\
\hline 5 & $\begin{array}{l}\text { Rehabilitation, sustainable management of natural vegetation, and economic development of non-timber forest } \\
\text { products in the Eastern Region of Burkina Faso }\end{array}$ \\
\hline 6 & Control of sand encroachment/mud silting in the river basins of Mouhoun, Nakanbé and Comoé \\
\hline 7 & Implementation of irrigated crops in Gourma, Namentenga, Tapoa and Sanmatnga regions \\
\hline 8 & Protection of pastoral-suited regions in the Sahelian and Eastern regions \\
\hline 9 & $\begin{array}{l}\text { Securing agricultural production through the use of appropriate technological packages in the South East and } \\
\text { East regions }\end{array}$ \\
\hline 10 & Promoting community-based fauna management in the Mouhoun Region \\
\hline 11 & $\begin{array}{l}\text { Implementation of safety zones and backup devices to control pollution of underground and surface water } \\
\text { catchment infrastructures (lakes, wells, boreholes) in the cotton belts of Burkina (Mouhoun, South West, Comoé and } \\
\text { the eastern part of Nakanbé) }\end{array}$ \\
\hline 12 & $\begin{array}{l}\text { Promoting the use of energy saving equipment (improved stoves, M'Bora stew pan) and renewable energy-based } \\
\text { technologies (pressure cooker, water heater and solar dryers, etc.) }\end{array}$ \\
\hline
\end{tabular}

Source: Adapted from SP/CONEDD (2007) 


\title{
Annex 5. Analyses of country reports-first national communication to UNFCCC
}

\author{
Indonesia
}

Country assessment (Source: State Ministry of Environment-Indonesia 1999)

Climate-change risks linked to forest indicated in the report

- High uncertainty in forest source/sink amount poses risk to future capability of meeting regulatory guidelines

- Increased frequency of fires as a result of climate change and careless use of fire in land clearing

Role of forests in the report in responding to national climate-change risks

- The report describes forests as a large sink with annual growth accounting for $686,790 \mathrm{Gg} \mathrm{CO}_{2}$ and that forest health is therefore important for mitigation

- Land use change and forestry account for $42.5 \%$ of total baseline emissions and the report indicates that accurate assessment of emissions from land use is critical to responding to climate risks

- National climate risks can be mitigated by better forest policy and enforcement of stronger regulations in forest management as stated in the report

- The report emphasises that research and development of sustainable forest practices will assist in reducing climate risk and will also build capacity to deal with future vulnerability

Potential use of TroFCCA research and other sources of forest information in addressing the national climate risks

- Climate-environment knowledge from tools created to forecast vulnerability in climate-sensitive regions for improving decisionsupport systems (IRI for Climate and Society 2008)

- TroFCCA-southeast Asia focus on fire management and sustainable forest management will help to inform adaptation strategy and goals expressed in the 1st National Communication

- Land-movement data will assist in charting areas of vulnerability potentially linking ecosystem pattern with climate change drivers, both of which will help with introducing scientific analysis into adaptation strategies for national development

\section{Burkina Faso}

Country assessment (Source: Burkina Faso 2001)

\section{Climate-change risks linked to forest indicated in the report}

- The productivity of the cotton industry and agriculture in general is vulnerable to climate change and climate variability. Specifically, the risk of droughts, floods, increased variability and reduction in available water over the long term will affect the productivity in this important industry

- Water resources for human consumption and irrigation are at risk due to changes in climate. Variability of precipitation, prolonged droughts and potential degradation of ecosystems (which help to regulate terrestrial water supply) will impact the availability of water resources

- Human health and wellbeing are at risk because of a higher proportion of respiratory illnesses related to the effects on air quality caused by climate change

- Forests in Burkina Faso are at risk from droughts, floods and greater variability in temperature and precipitation caused by climate change

- Biodiversity is at risk due to pressure on ecosystems imposed by climate change and variability

Role of forests in the report in responding to national climate-change risks

- Burkina Faso's national inventory of greenhouse gases shows that $1482 \mathrm{Gg}$ of $\mathrm{CO}_{2}$ is fixed by agriculture and land-use and landcover change. Forest information is essential to understanding the mechanisms of re-growth, carbon fixation, and climatechange mitigation and adaptation. Additionally, information pertaining to human use of ecosystems such as pastoralism and the social use of carbon is important to having credible greenhouse-gas inventory data

- Ecosystem function with respect to water availability is important for understanding potential effects of climate-change induced droughts. Understanding the spatial distribution of forest and the requirements of these ecosystems for water is important for understanding and reducing climate risks

- Information pertaining to the function and status of forests, and vegetation in general, will assist with adaptation programmes such as sustainable forest management, and land restoration. Sustainable forest management is a key adaptation strategy identified in the First National Communication 


\section{Country assessment (Source: Burkina Faso 2001)}

\section{Potential use of TroFCCA research and other sources of forest information in addressing the national climate risks}

- Maintenance of ecosystem goods and service provision to society, as well as maintenance of biodiversity, can only be achieved with quality scientific knowledge of how ecosystems operate. Burkina Faso's different biogeographical sectors (Sahelian, SubSahelian, North Soudanian and South Soudanian) must be understood from a scientific standpoint to see how climate change will affect ecosystems and societies in these regions

- Integrated land-use planning and the design of adaptive policies for forest use are important in making communities resilient to climate change. Conversion of land for industrial cotton production in central-south Burkina Faso has resulted in deforestation and displacement of farmers and pastoralists (CIFOR 2007). Adaptive management policies are necessary in these cases to respond to the cascading effects of land-use decisions. Forest information is also essential to know the underlying biophysical processes that provide goods and services for different actors. The effects of climate change on biophysical and social systems may be understood with a base of ecosystem information in conjunction with social and economic data

\section{Ghana}

Country assessment (Source: Republic of Ghana Ministry of Environment, Science, and Technology 2000)

\section{Climate-change risks linked to forest indicated in the report}

- Ground water and surface water runoff will be affected by climate change. The recharge and runoff rates will change due to reduced precipitation and higher temperatures. These changes to hydrological functions will pose a risk to society and require adaptation

- Irrigation water demand will be impacted by climate change. It is predicted that in the humid part of Ghana the irrigation demand in 2020 and 2050 will increase by $40 \%$ and $150 \%$, respectively, of the base-period water demand

- Human health and wellbeing are at risk due to changes to hydrological systems and air quality caused by climate change

- Hydroelectric supply is projected to be at risk from climate change, and models show a $60 \%$ reduction in capacity in some areas by 2020

- Agricultural productivity is threatened by increase in temperatures and reduction in precipitation in various agroclimatic zones. Models show that maize productivity will decrease by $6.9 \%$ by 2020

- Climate change is estimated to cause a $1 \mathrm{~m}$ sea level rise by 2100 , which will impact populations in the coastal zone as well as affecting natural habitats in this area

Role of forests in the report in responding to national climate-change risks

- Ghana's national inventory of greenhouse gases shows that $22,324 \mathrm{Gg}_{\text {of }} \mathrm{CO}_{2}$ is fixed by changes in forest and other woody biomass stock. Forest information is essential to managing the contribution of forest to climate-change mitigation and adaptation

- Water availability for irrigation and human consumption is a key risk in Ghana. Forests play an integral role in the hydrological cycle by regulating the ground and surface water flow, as well as buffering atmospheric and biosphere exchanges. In order to understand and mitigate risks caused by the water supply, the inter-relations of hydrological and ecological systems must be understood

- Policies related to land-use and land-cover change are important for climate-change mitigation and adaptation measures. Continuous monitoring of land use related to forestry and land-cover change will inform climate-change risk mitigation programmes

- Human health risks resulting from climate change impacts may be influenced by ecosystem activity. The role of forests in regulating water quality and availability, as well as ecosystem contribution to the propagation of vector-borne diseases, must be understood to mitigate these risks

\section{Potential use of TroFCCA research and other sources of forest information in addressing the national climate risks}

- Water scarcity and its relation to resource use and adaptation is a key aspect of development policy for Ghana, and TroFCCA work on forests will help to inform decision making related to development policy (Kalame et al. 2008; Gyampoh et al. 2008)

- An underlying requirement for countries in west Africa is to have adaptive policies that are applicable to the uncertainties and vulnerability that climate change poses to societies. TroFCCA work supports distributive and adaptive policy making linked to ecosystem research. In Ghana, the connections between ecosystem function, climate-change impacts and land-use conflicts are examined through field research programmes. The results of these studies can inform adaptation and mitigation initiatives for climate change (CIFOR 2007) 
Mali

Country assessment (Source: Republique du Mali Ministere d l'Equipement de l'Amanegement du Territoire de I'Environnement et de l'Urbanisme \& Ministere de l'Education 2000)

Climate-change risks linked to forest indicated in the report

- Agricultural productivity of crops such as sorghum/millet, maize and cotton is at risk

- Water resource availability for human consumption and irrigation is at risk

- Human health and wellbeing are potentially affected by climate change impacts on water quality, food provision, and through potentially increased exposure to disease

- Fish resources are at risk due to effects of climate change

- Changes to land use and forestry are at risk due to climate change and variability

- Biodiversity is at risk due to pressure on ecosystems imposed by climate change and variability

Role of forests in the report in responding to national climate-change risks

- Mali's national inventory of greenhouse gases shows that $10,828.88 \mathrm{Gg}_{\text {of }} \mathrm{CO}_{2}$ is fixed by agriculture and land-use and land-cover change. Forest information is essential to understanding the mechanisms of re-growth, carbon fixation, and climate-change mitigation and adaptation. Additionally, information pertaining to human use of ecosystems such as pastoralism and the social use of carbon is important to having credible greenhouse-gas inventory data

- Ecosystem function with respect to water availability is important for understanding potential effects of climate-change induced droughts. The history of drought in Mali shows that periods of prolonged drying can have effects on the persistence and resilience of vegetation in locations where human use of these ecosystems is critical

- Forests cover 100 million ha in Mali. Within this domain there is a variety of land uses, including agroforestry, conserved areas and intensive forest-resources use. Information pertaining to the function and status of forests will assist with adaptation programmes, such as sustainable forest management, land restoration, and use of forests for alternative energy programmes such as biofuels

Potential use of TroFCCA research and other sources of forest information in addressing the national climate risks

- The synergies between degradation of forests and desertification exacerbated by climate change must be identified in Mali. The synergies between forest resilience and biodiversity must also be recognised. The degradation of forests exacerbates the negative effects of climate change and it also impacts desertification and biodiversity (AMCE 2008)

- Integrated land-use planning and the design of adaptive policies for forest use are important in creating communities that are resilient to climate change. In Mali, land-use dynamics include large-scale industrial agriculture as well as small-scale pastoral land use. Rigid, top-down forest management policies have failed to address the changing needs of people reliant on ecosystems for livelihood products. TroFCCA work on the social use of ecosystems can inform forest policies that are adaptive to shocks of climate change (Forner et al. 2006)

- Ecosystem function in Mali in relation to changing parameters such as water availability must be clearly understood in order to respond to climate change. Resilience of ecosystems to environmental and social forces is critical to establishing prudent climate-change adaptation policy. In order to achieve this, capacity for systematic monitoring of the environment and social factors is necessary

\section{Costa Rica}

Country assessment (Source: República de Costa Rica Minsterio de Ambiente y Energía 2001)

Climate-change risks linked to forest indicated in the report

- Water resources may be affected by climate variation and change within the three main water basins and will impact human populations. With an increase in precipitation of 10-15\%, water runoff will increase by between 23.8 and $75.5 \%$. Alternatively, a decrease in precipitation of $10-15 \%$ will results in $5-29 \%$ reduction in runoff. Changes to the water cycle will affect runoff, erosion, and sediment load, causing flooding

- Impacts on the hydrological cycle will affect the hydroelectric supply capacity

- Coastal zone of Costa Rica (1300 km of coastline) is vulnerable to sea level rise. The coastline, which is primarily beaches in front of alluvial plains and salt marshes, will be vulnerable to the change in water level and a new equilibrium level will be reached. Residential areas such as in Puntarenas will be flooded 150-500 $\mathrm{m}$ from the original border

- Agricultural productivity will be affected by climate change. Rice, bean, potato and coffee production will either be increased or decreased depending on changes in parameters and time of year with the changes in precipitation, temperature and atmospheric $\mathrm{CO}_{2}$ concentration

- Ecosystem stability is threatened by climate change. Three different climate scenarios showed an increase in pre-montane, wet and lower montane forests, whereas there was a consistent decrease in montane, tropical and rain forests. The density of life in rainforests is threatened by climate change 


\section{Country assessment (Source: República de Costa Rica Minsterio de Ambiente y Energía 2001)}

\section{Role of forests in the report in responding to national climate-change risks}

- The national inventory of greenhouse gases shows that $4337.7 \mathrm{Gg}$ of $\mathrm{CO}_{2}$ is fixed by the combined effect of tree growth and regeneration of abandoned pastures. Forest information is essential to understanding the mechanisms of regrowth, carbon fixation, and climate-change mitigation and adaptation. Costa Rica has very diverse forest types and ecosystem research will be crucial

- Changes in the state of ecosystems in response to climate-change predictions demonstrate a significant risk, especially in the rain forest areas, as well as in tropical and montane forests. Knowledge of these ecosystems will assist in understanding and responding to risk and impacts of changes

- Changes to hydrological processes in the three main water basins are a key factor in climate change in Costa Rica. Forests play a part in regulating this risk, such as in the areas near rivers where instability or sedimentation may occur

- Conservation of forests through payment for environmental services is one way of responding to climate change in Costa Rica. Payment for environmental services programmes are already in place in Costa Rica.

Potential use of TroFCCA research and other sources of forest information in addressing the national climate risks

- Research on the understanding of how forests interact within water basins is critical to responding to the effects of climate change on water systems. Additionally, impacts on hydroelectric supply can be also be addressed by research on ecosystems (Leguia et al. 2008)

- Research on ecosystems, agroforestry and vulnerability to drought can help to develop adaptive capacity with respect to climate variability and extreme weather events (Pérez et al. 2007b)

- How ecosystems change and adapt to climate change is important in understanding how forests may change, as well as how different environmental parameters may contribute to ecosystem changes in various contexts. TroFCCA research on forest species change will inform this area (Cervi et al. 2007)

\section{Honduras}

Country assessment (Source: República de Honduras Secretaria de Recursos Naturales y Ambiente 2000)

\section{Climate-change risks linked to forest indicated in the report}

- Climate-change induced droughts pose risk to the populations in dry areas in the form of extreme hunger, death, water-borne diseases, cardiovascular diseases and respiratory illnesses due to atmospheric contamination and extreme temperatures

- Higher frequencies of forest fires in drought episodes pose risk to society

- Precipitation events, such as those associated with Hurricane Mitch, pose risk to human populations and infrastructure

- Agricultural industries, such as maize cultivation, are vulnerable to climate variability and also water limitations from future higher atmospheric temperatures

- Communities on the Caribbean coast are threatened with the risk of sea level rise

- Greenhouse gas mitigation in Honduras is in part reliant on fixation of carbon by forests. Without accurate estimates of the amount of carbon sequestered, greater risk will be posed to Honduras in its efforts to meet the mitigation goals

\section{Role of forests in the report in responding to national climate-change risks}

- The inventory of $\mathrm{CO}_{2}$ is in part influenced by the fixation of the gas by forests. In the land-use and land-change sector there are $54,111.16 \mathrm{Gg}$ emitted and $52,763.11 \mathrm{Gg}$ fixed. The balance is $1380.05 \mathrm{Gg}$. Forests play a major role in the fixation and balancing of carbon budgets

- Ecosystem resilience, structure and function influence the hydrological processes and are important to understanding the relationship with risk of forest fires. Forest knowledge can facilitate response to social and economic vulnerability

- Vulnerability to water shortage-a key risk factor_can be addressed with ecological and hydrological function. More intact ecosystems inhibit arid landscapes from forming in the face of climate change drivers

- Conservation of forests through protection and economic evaluation is a valid response for mitigation and adaptation to climate change in Honduras

Potential use of TroFCCA research and other sources of forest information in addressing the national climate risks

- The assessment of the role of ecosystems in providing potable water in the drought-vulnerable western region will help with the response to climate-change risk (Najarro 2007)

- Analysing the contribution of ecosystems in the supply of hydroelectric power will help manage social and economic risks to climate change and variability (Coto 2006; Najarro 2007)

- Research on including ecosystems in adaptation policy will help conceptually link on-the-ground research with national sustainable-development policy (Pérez 2006) 


\section{Nicaragua}

Country assessment (Source: República de Nicaragua 2001)

Climate-change risks linked to forest indicated in the report

- Reduced precipitation shown in climate models in the northern regions and municipalities of Chinandega and Leon pose risk to agriculture and cattle industries

- Uncertainty in land-use and land-cover change on $\mathrm{CO}_{2}$ emissions impacts the validity of inventory and may pose problems with respect to meeting climate-change regulatory guidelines

- A growing population may be at risk of water supply shortages for human consumption, irrigation and electricity generation

- Ecosystems face the possibility of changing to more dry states through 2050 and 2100 due to reduced precipitation in certain regions. There is a chance of the Very Dry Forest (Holdridge Classification) to be dominant in North Pacific region (near Leon)

- Higher incidences of malaria may occur as a result of changing climate and the resulting better conditions for vector species to flourish

Role of forests in the report in responding to national climate-change risks

- The national inventory of greenhouse gases shows that $72,429 \mathrm{Gg}$ of $\mathrm{CO}_{2}$ is fixed by the combined effects of tree growth and regeneration of abandoned pastures. Forest information is essential to understanding the mechanisms of re-growth, carbon fixation, and climate change mitigation and adaptation

- Changes in the state of ecosystems (based on Holdridge system) in response to climate-change predictions is a significant risk, especially in the area of Leon and Chinandega. Forest water demands and ecological resilience are important to mitigate social and economic effects of climate change

- Water availability is cited as one of the most significant risks posed by climate change in Nicaragua. Forests play a part in the response to this risk by promoting their conservation and regeneration in areas of hydrological vulnerability-such as in areas of close proximity to rivers (riparian zones)

- Conservation of forests through protection and also economic evaluation is a valid response for mitigation and adaptation to climate change in Nicaragua

Potential use of TroFCCA research and other sources of forest information in addressing the national climate risks

- Forests are integral in mitigating and adapting to climate-imposed risks to the hydroelectric industry. Research and understanding of how forests interact with the hydrological cycle, particularly in relation to watersheds, will inform adaptation policy (Leguía et al. 2007)

- TroFCCA research on ecosystems, agroforestry and vulnerability to drought can help to create adaptive capacity with respect to climate variability and extreme weather events (Pérez et al. 2007b)

- The supply of potable water is noted as an source of acute risk to some regions, such as San Pedro del Norte (Gonzales et al. 2007; Pérez et al. 2007a). TroFCCA-provided knowledge of forest function with respect to provision of ecosystem services such as water regulation and supply will assist with development of adaptive management policy (Locatelli 2006) 


